\title{
POLA KONSUMSI TAHU DAN TEMPE PADA KELUARGA PRASEJAHTERA (KASUS DI KELURAHAN WAY LUNIK KECAMATAN PANJANG BANDAR LAMPUNG)
}

\author{
(The Consumption Pattern of Tofu and Tempe by Underprivilage Families, Case at Way Lunik Village \\ Panjang Subdistrict in Bandar Lampung)
}

Muhammad Reza Azhar, Wan Abbas Zakaria, Rabiatul Adawiyah

Jurusan Agribisnis, Fakultas Pertanian, Universitas Lampung, Jl. Prof. Dr. Soemantri Brodjonegoro No.1 Bandar Lampung 35145, e-mail: rezaazhar95@gmail.com

\begin{abstract}
This research aimed to know the pattern of tofu and tempe consumption, and factors that affected tofu and tempe consumption. The method used in this research was survay in which location was chosen purposively at Way Lunik village, Panjang Subdistrict, Bandar Lampung. This research employed 60 sample families, in which housewives saved as respondents. The data were taken in August 2017 and analyzed quantitatively by multiple linier regression and descriptive method. The result showed that the average of total consumption of tofu by underprivilage families was 2,017.50 grams/week or 288.21 grams/day, while for tempe was $1,296.50$ grams/week or 185.21 grams/day. Underprivilage families ate tofu and tempe very often. Consumption purposes of tofu and tempe was for pleasure and habit in which processing use deep frying and being sauteed. Underprivilage families consumpted tofu and tempe by buying. Factors that affected on tofu consumption by underprivilage families were tofu price, chicken egg price, and number of family members; while factors that affected on tempe consumption by underprivilage families were salted fish price, chicken egg price, family income and the number of family members.
\end{abstract}

Key words: consumption pattern, tempe, tofu, underprivilage families

\section{PENDAHULUAN}

Permasalahan pangan di Indonesia sekarang ini dihadapkan pada keterbatasan stok pangan dan ketergantungan terhadap satu jenis tanaman pangan. Salah satu kendala bahwa percepatan luas lahan tanaman pangan tertentu tidak selalu dapat mengimbangi percepatan pertumbuhan penduduk. Seiring dengan peningkatan jumlah penduduk dan kesejahteraan masyarakat, maka kebutuhan terhadap jenis dan kualitas produk makanan juga semakin meningkat dan beragam (Badan Ketahanan Pangan 2015).

Kedelai adalah salah satu tanaman pangan yang penting di Indonesia dan merupakan satu dari lima komoditas utama di Indonesia dengan target swasembada tahun 2014. Kedelai mengandung gizi yang tinggi karena mengandung protein nabati dan anti-oksidan. Olahan biji kedelai dapat dibuat menjadi berbagai bentuk seperti tahu, tempe, kecap, susu kedelai, tepung kedelai, minyak kedelai, serta taosi atau tauco.

Tahu dan tempe merupakan produk olahan biji kedelai yang cukup digemari masyarakat Indonesia. Tahu dan tempe termasuk lauk yang bergizi tinggi dan rendah kolesterol. Kandungan protein dalam 100 gram tahu adalah 7,8 persen dan pada 100 gram tempe terdapat 18,3 persen protein (Departemen Kesehatan 2015). Kandungan protein yang cukup tinggi menjadikan tahu dan tempe sebagai alternatif dalam pemenuhan kebutuhan protein.

Produsen tahu dan tempe cukup berkembang di Bandar Lampung. Pengrajin tahu dan tempe di Bandar Lampung berjumlah 542 unit dengan rincian 128 unit pengrajin tahu, 59 unit pengrajin tempe, dan 355 unit pengrajin tahu dan tempe. Hasil produksi dipasarkan di sekitar Kota Bandar Lampung (Dinas Koperasi dan UMKM Provinsi Lampung 2016).

Pola konsumsi suatu masyarakat mencerminkan tingkat kesejahteraan masyarakat terutama dalam bidang perekonomian yang mengakibatkan perbedaan pola konsumsi antar rumah tangga. Perbedaan kuantitas dan kualitas konsumsi antar rumah tangga dikarenakan berbedanya pendapatan, jumlah tanggungan, jabatan, kebutuhan tiap-tiap rumah tangga (Suhardjo 1986). Rata-rata konsumsi protein per kapita per hari kelompok kacang-kacangan di Kota Bandar Lampung pada tahun 2016 sebesar 5,52 gr/kapita/hari (BPS Provinsi Lampung 2016). 
Berdasarkan Susenas Maret 2017, rata-rata konsumsi protein per kapita per hari kelompok kacang-kacangan di Indonesia adalah sebesar 5,63 gr/kapita/hari (BPS 2017). Konsumsi kelompok makanan kacang-kacangan di Kota Bandar Lampung masih dibawah rata- rata nasional.

Kecamatan Panjang merupakan salah satu kecamatan yang ada di Kota Bandar Lampung dan termasuk dalam kecamatan dengan jumlah keluarga prasejahtera terbanyak di Bandar Lampung pada tahun 2014. Kelurahan Way Lunik merupakan kelurahan di Kecamatan Panjang dengan jumlah keluarga prasejahtera terbanyak (BPS Kota Bandar Lampung 2015). Keluarga prasejahtera adalah keluarga yang tidak memenuhi salah satu dari 6 (enam) indikator Keluarga Sejahtera I (KS I) atau indikator kebutuhan dasar keluarga (basic needs).

Pola konsumsi dapat dilihat pada jumlah, frekuensi dan, tujuan konsumsi; cara mengolah dan cara memperolehnya. Berdasarkan uraian tersebut, maka tujuan penelitian ini adalah untuk mengetahui pola konsumsi tahu tempe dan faktorfaktor yang mempengaruhi jumlah konsumsi tahu tempe pada keluarga prasejahtera di Kelurahan Way Lunik Kecamatan Panjang Kota Bandar Lampung.

\section{METODE PENELITIAN}

Metode penelitian yang digunakan adalah metode survei di Kelurahan Way Lunik, Kecamatan Panjang, Bandar Lampung. Lokasi penelitian dipilih secara sengaja (purposive) dengan pertimbangan Kelurahan Way Lunik merupakan kelurahan dengan jumlah keluarga prasejahtera terbanyak di Bandar Lampung. Pengambilan data dilakukan pada bulan Agustus 2017.

Jumlah sampel ditentukan dengan menggunakan rumus Isaac dalam Sugiarto et al. (2003), yaitu :

$\mathrm{n}=\frac{\mathrm{N} \cdot \mathrm{Z}^{2} \cdot \mathrm{S}^{2}}{\mathrm{Nd}^{2}+\mathrm{Z}^{2} \mathrm{~S}^{2}}$

Keterangan :

$\mathrm{n}=$ Jumlah sampel

$\mathrm{N}=$ Jumlah populasi keluarga prasejahtera di Kelurahan Way Lunik

$S^{2}=$ Variasi sampel $(5 \%)=0,05$

$\mathrm{Z}=$ Tingkat Kepercayaan $(90 \%)=1,645$

$\mathrm{d}=$ Derajat Penyimpangan $(5 \%)=0,05$
Berdasarkan perhitungan tersebut, maka diperoleh 52 sampel. Jumlah sampel yang digunakan dalam penelitian ini adalah 60 rumah tangga dengan asumsi semakin besar jumlah sampel akan menambah variasi sampel. Responden penelitian adalah ibu rumah tangga keluarga prasejahtera.

Data yang digunakan dalam penelitian ini adalah data primer dan data sekunder. Data primer diperoleh secara langsung melalui proses wawancara. Data sekunder diperoleh dari badan dan instansi terkait di daerah penelitian.

Metode analisis deskriptif digunakan untuk menjawab tujuan pertama yaitu pola konsumsi tahu dan tempe yaitu jumlah konsumsi, frekuensi konsumsi, tujuan konsumsi, cara mengonsumsi dan cara memperoleh. Analisis data secara kuantitatif digunakan untuk menjawab tujuan dalam penelitian ini yaitu faktor-faktor yang mempengaruhi jumlah konsumsi tahu dan tempe oleh rumah tangga di Kota Bandar Lampung dengan menggunakan model regresi linier berganda. Model yang digunakan untuk mencari faktor yang mempengaruhi konsumsi tahu dapat dirumuskan sebagai berikut :

$$
\mathrm{Y}=\begin{aligned}
& \mathrm{b}_{0}+\mathrm{b}_{1} \mathrm{X}_{1}+\mathrm{b}_{2} \mathrm{X}_{2}+\mathrm{b}_{3} \mathrm{X}_{3}+\mathrm{b}_{4} \mathrm{X}_{5}+\mathrm{b}_{6} \mathrm{X}_{6}+ \\
& \mathrm{b}_{7} \mathrm{X}_{7}+\mathrm{d}_{1} \mathrm{D}_{1}+\mathrm{u} \ldots \ldots \ldots \ldots \ldots \ldots \ldots \ldots \ldots \ldots \ldots \ldots \ldots \ldots \ldots \ldots \ldots \ldots \ldots \ldots \ldots \ldots
\end{aligned}
$$

Untuk menduga parameter model, maka persamaan tersebut ditransformasikan ke dalam bentuk logaritma natural (ln) sehingga diperoleh persamaan sebagai berikut :

$$
\begin{aligned}
\ln \mathrm{Y}= & \operatorname{lnb} 0+\mathrm{b} 1 \ln \mathrm{X} 1+\mathrm{b}_{2} \ln \mathrm{X}_{2}+\mathrm{b}_{3} \ln \mathrm{X}_{3}+ \\
& \mathrm{b}_{4} \ln \mathrm{X}_{4}+\mathrm{b}_{5} \ln \mathrm{X}_{5}+\mathrm{b}_{6} \ln \mathrm{X}_{6}+\mathrm{b}_{7} \ln \mathrm{X}_{7}+\mathrm{d}_{1} \mathrm{D}_{1} \\
& +\mathrm{e}^{\mathrm{u}} \ldots \ldots \ldots \ldots \ldots \ldots \ldots \ldots \ldots \ldots \ldots \ldots \ldots \ldots \ldots \ldots \ldots \ldots \ldots \ldots \ldots \ldots \ldots \ldots \ldots \ldots \ldots \ldots
\end{aligned}
$$

$$
\begin{aligned}
& \text { Keterangan : } \\
& \mathrm{Y}=\text { Jumlah konsumsi tahu }(\mathrm{Kg}) \\
& \mathrm{b}_{0}=\text { Intersep } \\
& \mathrm{b}_{1}-\mathrm{b}_{7}=\text { Koefisien variable bebas } \\
& \mathrm{X}_{1}=\text { Harga tahu }(\mathrm{Rp} / \mathrm{kg}) \\
& \mathrm{X}_{2}=\text { Harga tempe }(\mathrm{Rp} / \mathrm{kg}) \\
& \mathrm{X}_{3}=\text { Harga ikan segar }(\mathrm{Rp} / \mathrm{kg}) \\
& \mathrm{X}_{4}=\text { Harga ikan asin }(\mathrm{Rp} / \mathrm{kg}) \\
& \mathrm{X}_{5}=\text { Harga telur ayam }(\mathrm{Rp} / \mathrm{kg}) \\
& \mathrm{X}_{6}=\text { Pendapatan keluarga }(\mathrm{Rp} / \mathrm{bulan}) \\
& \mathrm{X}_{7}= \text { Jumlah anggota keluarga (jiwa) } \\
& \mathrm{D}_{1}= \text { Tingkat pendidikan dimana D = 1 jika } \\
& \text { tingkat pendidikan minimal SLTA dan D } \\
&=0 \text { jika tingkat pendidikan selain SLTA } \\
& \mathrm{u}= \text { Kesalahan acak (error term) } \\
& \mathrm{e}= \text { Bilangan normal }
\end{aligned}
$$


Fungsi yang digunakan untuk mencari faktor yang mempengaruhi konsumsi tempe dapat dirumuskan sebagai berikut :

$$
\begin{aligned}
\mathrm{Y}= & \mathrm{b}_{0}+\mathrm{b}_{1} \mathrm{X}_{1}+\mathrm{b}_{2} \mathrm{X}_{2}+\mathrm{b}_{3} \mathrm{X}_{3}+\mathrm{b}_{4} \mathrm{X}_{4}+\mathrm{b}_{5} \mathrm{X}_{5}+ \\
& \left.\mathrm{b}_{6} \mathrm{X}_{6}+\mathrm{b}_{7} \mathrm{X}_{7}+\mathrm{d}_{1} \mathrm{D}_{1}+\mathrm{u} \ldots \ldots \ldots \ldots \ldots . . .14\right)
\end{aligned}
$$

Untuk menduga parameter model, maka persamaan tersebut ditransformasikan ke dalam bentuk logaritma natural (ln) sehingga diperoleh persamaan sebagai berikut :

$$
\begin{aligned}
& \ln Y=\ln b_{0}+b_{1} \ln X_{1}+b_{2} \ln X_{2}+b_{3} \ln X_{3}+b_{4} \ln X_{4}+ \\
& b_{5} \ln X_{5}+b_{6} \ln X_{6}+b_{7} \ln X_{7}+d_{1} D_{1}+e^{u} \ldots
\end{aligned}
$$

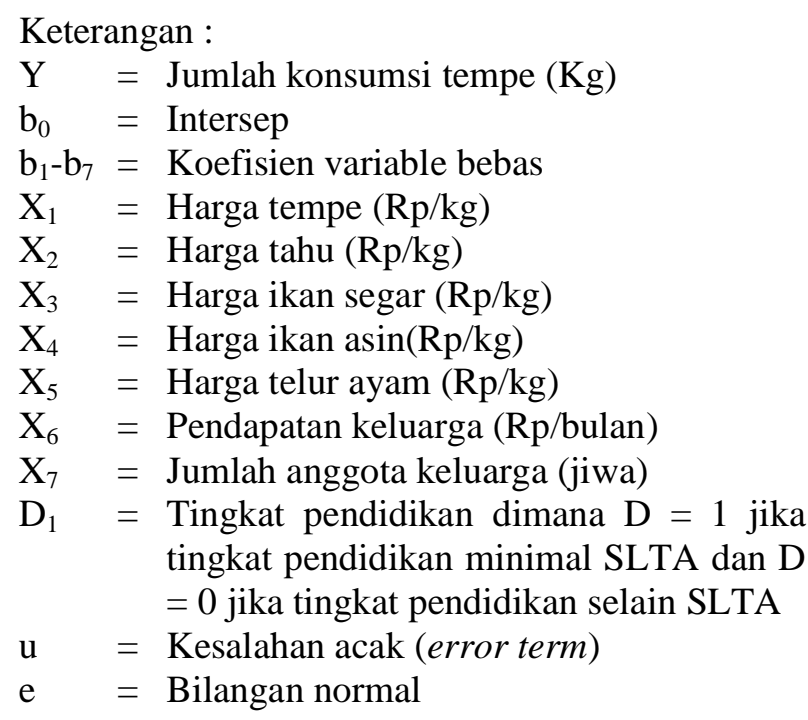

\section{HASIL DAN PEMBAHASAN}

\section{Gambaran Umum Daerah Penelitian}

Kelurahan Way Lunik merupakan salah satu wilayah kelurahan yang berada di Kecamatan Panjang. Luas wilayah dari Kelurahan Way Lunik adalah seluas 144 ha dengan persentase terhadap luas kecamatan sebesar 8,04 persen. Kelurahan Way Lunik memiliki tinggi rata-rata sebesar 11 meter di atas permukaan laut. Kelurahan Way Lunik mempunyai dua lingkungan (LK) dan 35 Rukun Tetangga (RT).

Jumlah penduduk di Kelurahan Way Lunik pada tahun 2017 adalah sebanyak 8.286 jiwa terdiri dari 3.973 jiwa laki-laki, dan 4.313 jiwa perempuan. KK di Kelurahan Way Lunik pada tahun 2017 berjumlah $2.011 \mathrm{KK}$ dengan jumlah keluarga prasejahtera yaitu sebanyak $1.104 \mathrm{KK}(54,89 \%)$ pada tahun 2014. Sebagian besar mata pencarian penduduk Kelurahan Way Lunik adalah buruh sebanyak 34,61 persen dan sebagian besar bekerja di industri kategori sedang sampai besar yang bergerak di bidang hasil bumi, kimia, dan semen yang terdapat di Kelurahan Way Lunik. Sebagian besar penduduk yang bekerja sebagai buruh di industri penghasilannya kurang menentu sehingga sulit untuk memenuhi kebutuhan hidupnya.

\section{Karakteristik Umum Responden}

Umur responden 21 sampai 59 tahun dengan ratarata 40 tahun. Tingkat pendidikan responden tamat SLTP $(50 \%)$ yang termasuk dalam kategori pendidikan rendah. Mata pencaharian responden adalah ibu rumah tangga dan terdapat sembilan responden mempunyai pekerjaan sampingan sebagai wirausaha dan tiga orang sebagai buruh. Sebagian besar responden $(38,33 \%)$ adalah etnis Jawa. Jumlah anggota keluarga responden sebanyak tiga sampai enam orang dengan rata-rata 4 orang/keluarga. Rata-rata pendapatan responden pada penelitian ini yaitu sebesar Rp2.156.666,00/ bulan.

\section{Pola Konsumsi Tahu dan Tempe}

Pola konsumsi adalah kegiatan mengonsumsi pangan untuk memenuhi kebutuhan gizi yang diperlukan oleh tubuh. Pola konsumsi dalam penelitian ini dapat diketahui melalui lima hal yaitu jumlah konsumsi, frekuensi konsumsi, tujuan konsumsi, cara mengolah, dan cara memperoleh.

Data pada Tabel 1 menunjukkan bahwa rata-rata jumlah konsumsi tahu dalam satu minggu sebesar 2.017,50 gram/minggu atau 288,21 gram/hari, sedangkan untuk tempe sebesar 1.296,50 gram/minggu atau 185,21 gram/hari. Rata-rata jumlah anggota keluarga yang mengonsumsi tahu dan tempe adalah 4 orang. Jumlah konsumsi tahu per kapita per minggu adalah 483,81 gram dan untuk tempe adalah 310,16 gram. Jumlah tersebut lebih besar dibandingkan dengan masyarakat Provinsi Lampung dan Indonesia tahun 2016 yaitu yaitu 107,33 gram dan 182,00 gram di Provinsi Lampung, sedangkan di Indonesia 151 gram dan 141 gram (BPS Provinsi Lampung 2016).

Berdasarkan penelitian diketahui bahwa suku responden dengan etnis Jawa merupakan etnis yang paling banyak mengonsumsi tahu dan tempe dengan masing-masing berjumlah 23 orang, sedangkan etnis Lampung merupakan yang terendah dengan jumlah sembilan orang. Berdasarkan survei menurut Beritagar.id tahun 2017, tiga provinsi dengan jumlah konsumsi tahu dan tempe terbanyak di Indonesia adalah Jawa Timur, Jawa Tengah, dan DI Yogyakarta. Dapat 
disimpulkan bahwa etnis Jawa berpengaruh besar terhadap jumlah konsumsi tahu dan tempe di lokasi penelitian. Hal tersebut sesuai dengan pernyataan Indriani (2014) yaitu pola sosial dan budaya dapat mempengaruhi pola konsumsi seseorang.

Frekuensi konsumsi tahu dan tempe menunjukkan seberapa sering rumah tangga responden dalam mengonsumsi tahu dan tempe dalam jangka waktu seminggu. Sebagian besar rumah tangga di lokasi penelitian mengonsumsi tahu dan tempe lebih dari 1x/ hari,sehingga frekuensi konsumsi tahu dan tempe termasuk sangat sering (Suhardjo 1989). Rata-rata frekuensi konsumsi tahu dan tempe oleh rumah tangga responden adalah sebanyak 18,08 kali/minggu dan 18,78 kali/minggu. Rata-rata frekuensi konsumsi tahu dan tempe pada penelitian ini lebih besar dibandingkan dengan penelitian Jayati (2014) yaitu frekuensi konsumsi pangan tahu dan tempe di Kasepuhan Ciptagelar, Provinsi Jawa Barat adalah sebanyak 2,3-2,9 kali/minggu. Frekuensi konsumsi berpengaruh terhadap jumlah tahu atau tempe yang dikonsumsi keluarga responden. Semakin tinggi frekuensi konsumsi, maka jumlah konsumsinya semakin banyak.

Tujuan konsumsi tahu dan tempe dibagi menjadi tiga yaitu tujuan kesukaan, kesehatan dan kebiasaan. Sebagian besar tujuan responden dalam mengonsumsi tahu dan tempe adalah karena kesukaan dan kebiasaan dengan persentase sebesar 25,00 dan 26,67 persen. Tujuan konsumsi berhubungan dengan frekuensi konsumsi. Frekuensi konsumsi tahu tempe yang sangat sering menunjukkan responden suka dan terbiasa mengonsumsi tahu dan tempe. Menurut Indriani (2014), seseorang pasti lebih memilih sumber pangan yang telah dikenal dan disukainya sehingga jumlah dan frekuensi konsumsinya lebih banyak dibandingkan sumber pangan yang lain.

Cara mengolah tahu dan tempe adalah cara yang dilakukan responden untuk mengolah tahu dan tempe hingga siap untuk dikonsumsi. Mayoritas responden memilih cara mengolah tahu dan tempe adalah dengan digoreng dan ditumis yaitu sebesar 38,33 dan 36,67 persen.

Tabel 1. Rata-rata jumlah konsumsi tahu dan tempe oleh rumah tangga responden

\begin{tabular}{lccc}
\hline Produk & $\begin{array}{c}\text { Rata-rata } \\
\text { jumlah } \\
\text { konsumsi } \\
\text { (gram/minggu) }\end{array}$ & $\begin{array}{c}\text { Rata-rata } \\
\text { jumlah } \\
\text { konsumsi } \\
\text { (gram/hari) }\end{array}$ & $\begin{array}{c}\text { Jumlah } \\
\text { konsumsi per } \\
\text { kapita } \\
\text { (gram/minggu) }\end{array}$ \\
\hline Tahu & $2.017,50$ & 288,21 & 483,81 \\
Tempe & $1.296,50$ & 185,21 & 310,16 \\
\hline
\end{tabular}

Hal ini karena mudah dan cepat untuk dilakukan. Penelitian ini sejalan dengan penelitian Apriani, Yuliana, dan Kasmita (2012) yaitu cara memasak ikan untuk dikonsumsi yang sering dilakukan responden adalah dengan teknik menggoreng dan menggulai masing-masing sebesar 34,30 persen.

Cara memperoleh tahu dan tempe dilakukan dengan membeli $(95,00 \%$ dan $96,67 \%)$, sisanya berasal dari pemberian dari orang lain. Tidak ada responden yang memperoleh tahu dan tempe dengan cara memproduksi sendiri karena responden bukan produsen tahu dan tempe.

\section{Faktor- faktor yang Mempengaruhi Jumlah Konsumsi Tahu}

Hasil analisis faktor-faktor yang mempengaruhi jumlah konsumsi tahu dapat dilihat pada Tabel 2. Berdasarkan uji menggunakan metode stepwise, terdapat tiga variabel bebas yang berpengaruh nyata terhadap jumlah konsumsi tahu yaitu adalah harga tahu $\left(\mathrm{X}_{1}\right)$, harga telur ayam $\left(\mathrm{X}_{5}\right)$, dan jumlah anggota keluarga $\left(X_{7}\right)$, sedangkan variabel harga tempe $\left(X_{2}\right)$, harga ikan segar $\left(X_{3}\right)$, harga ikan asin $\left(\mathrm{X}_{4}\right)$, pendapatan keluarga $\left(\mathrm{X}_{6}\right)$, dan tingkat pendidikan ibu rumah tangga $\left(D_{1}\right)$ tidak berpengaruh nyata terhadap jumlah konsumsi tahu sehingga tidak dimasukkan ke dalam model.

Data pada Tabel 2 menunjukkan koefisien determinasi $\left(R^{2}\right) 0,260$. Hal tersebut berarti bahwa sebesar 26 persen variasi jumlah konsumsi tahu dapat dijelaskan oleh variasi variabel harga tahu, harga telur ayam, dan jumlah anggota keluarga Sisanya sebesar 74 persen dijelaskan oleh variabel lain yang tidak dimasukkan ke dalam model yang diuji pada penelitian ini.

Nilai $F$ hitung pada penelitian ini adalah 6,561 yang berbeda nyata dari $F$ tabel pada taraf kepercayaan 99 persen. Hal tersebut berarti bahwa variabel harga tahu, harga telur ayam, dan jumlah anggota keluarga secara bersama-sama berpengaruh nyata terhadap jumlah konsumsi tahu dengan tingkat kepercayaan 99 persen.

Secara matematis bentuk model fungsi faktorfaktor yang mempengaruhi jumlah konsumsi tahu adalah

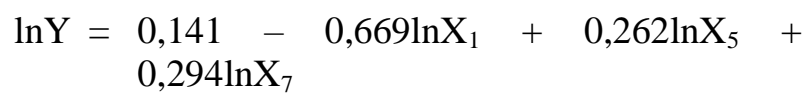


Tabel 2. Hasil analisis regresi linier berganda faktor-faktor yang mempengaruhi jumlah konsumsi tahu

\begin{tabular}{lccc}
\hline \multicolumn{1}{c}{ Variabel } & Koefisien & Sign & VIF \\
\hline Konstanta $(\mathrm{C})$ & $-1,960$ & 0,049 & \\
Harga tahu $\left(\mathrm{X}_{1}\right)$ & $-0,669 * * *$ & 0,001 & 1,111 \\
Harga telur ayam & $0,262 * *$ & 0,016 & 1,074 \\
$\left(\mathrm{X}_{5}\right)$ & & & \\
Jumlah anggota & $0,294 *$ & 0,206 & 1,039 \\
keluarga $\left(\mathrm{X}_{7}\right)$ & & & \\
\hline F-hitung & 6,561 & 0,001 & \\
R-squared $\left(\mathrm{R}^{2}\right)$ & 0,260 & & \\
Adj R-Squared & 0,220 & & \\
Keterangan : *** Taraf signifikasi sebesar 99\% & \\
& $* *$ Taraf signifikasi sebesar 95\% & \\
$*$ Taraf signifikasi sebesar 75\% &
\end{tabular}

Berdasarkan hasil analisis regresi, model regresi ini dapat dikatakan baik karena tidak ditemukan masalah multikolinieritas dan heterokedastitas. Nilai VIF variabel bebas penelitian ini kurang dari 10 dan nilai nilai probabilitas (chi-squared) pada penelitian ini adalah 0,5655 yang artinya lebih besar dari 0,05 .

Harga tahu berpengaruh nyata terhadap jumlah konsumsi tahu dengan tingkat kepercayaan 99 persen. Nilai koefisien antara variabel harga tahu dengan jumlah konsumsi tahu bernilai negatif yaitu sebesar-0,669. Hal tersebut berarti jika harga tahu meningkat sebesar 100 persen, maka jumlah konsumsi tahu akan menurun sebesar 66,90 persen $(1,34 \mathrm{~kg})$. Hasil tersebut sesuai dengan teori permintaan yaitu apabila terjadi kenaikan harga suatu barang maka akan menyebabkan penurunan permintaan terhadap barang itu sendiri (Sukirno 2003). Penelitian ini sejalan dengan penelitian tentang olahan kedelai lainnya oleh Ariesman, Prasmatiwi dan Indriani (2015) yaitu harga kecap manis berpengaruh nyata negatif terhadap permintaan kecap manis di Bandar Lampung.

Harga telur ayam merupakan salah satu variabel yang berpengaruh nyata terhadap jumlah konsumsi tahu dengan tingkat kepercayaan 95 persen. Nilai koefisien antara variabel harga telur ayam dengan jumlah konsumsi bernilai positif yaitu sebesar 0,262 . Artinya setiap kenaikan harga telur ayam sebesar 100 persen, maka jumlah konsumsi tahu akan meningkat sebesar 26,20 persen $(0,52 \mathrm{~kg})$. Berdasarkan teori elastisitas, dapat diketahui bahwa antara tahu dan telur ayam merupakan barang substitusi. Saat harga telur ayam naik, keluarga prasejahtera memilih mengganti lauk sumber proteinnya dengan tahu karena harganya yang lebih murah dibandingkan telur ayam. Penelitian ini tidak sejalan dengan penelitian
Hanafi, Daris, dan Rochaeni (2014) yang menyatakan bahwa harga telur ayam tidak berpengaruh nyata terhadap permintaan tempe di Kelurahan Jurangmangu Timur.

Jumlah anggota keluarga merupakan salah satu faktor yang berpengaruh nyata terhadap jumlah konsumsi tahu dengan tingkat kepercayaan 75 persen dan koefisien regresi sebesar 0,294. Artinya setiap terjadi kenaikan jumlah anggota keluarga sebesar 100 persen, maka jumlah konsumsi tahu akan meningkat sebesar 29,40 persen $(0,59 \mathrm{~kg})$. Semakin banyak jumlah anggota keluarga maka jumlah tahu yang dikonsumsi lebih banyak. Hasil penelitian ini bertolak belakang dengan penelitian pada protein hewani oleh Parulian, Lestari, dan Adawiyah (2014) dimana jumlah anggota keluarga tidak mempengaruhi permintaan daging sapi di Bandar Lampung.

\section{Faktor-faktor yang Mempengaruhi Permintaan Tempe}

Hasil analisis faktor-faktor yang mempengaruhi jumlah konsumsi tempe dapat dilihat pada Tabel 3. Data pada Tabel 3 menunjukkan model regresi terbaik dengan menggunakan metode stepwise. Variabel bebas yang berpengaruh nyata terhadap jumlah konsumsi tempe yaitu harga ikan asin $\left(X_{4}\right)$, harga telur ayam $\left(\mathrm{X}_{5}\right)$, pendapatan keluarga $\left(\mathrm{X}_{6}\right)$, dan jumlah anggota keluarga $\left(\mathrm{X}_{7}\right)$, sedangkan variabel harga tahu $\left(\mathrm{X}_{1}\right)$ tidak berpengaruh nyata. Harga tempe $\left(X_{2}\right)$, harga ikan segar $\left(X_{3}\right)$, pendapatan keluarga $\left(\mathrm{X}_{6}\right)$, dan tingkat pendidikan $\left(\mathrm{D}_{1}\right)$ tidak dimasukkan ke dalam model.

Data pada Tabel 3 menunjukkan nilai koefisien determinasi $\left(\mathbf{R}^{2}\right) 0,290$. Hal tersebut berarti bahwa sebesar 29 persen variasi jumlah konsumsi tempe dapat dijelaskan oleh variasi variabel harga tahu, harga ikan asin, harga telur ayam, pendapatan keluarga, dan jumlah anggota keluarga. Sisanya sebesar 71 persen dapat dijelaskan oleh variabel lain yang tidak dimasukkan ke dalam model yang diuji pada penelitian ini.

Nilai $\mathrm{F}$ hitung pada penelitian ini adalah 4,401 dengan nilai signifikan sebesar 0,002 . Hal tersebut berarti bahwa variabel harga tahu, harga ikan asin, harga telur ayam, pendapatan keluarga, dan jumlah anggota keluarga secara bersama-sama berpengaruh nyata terhadap jumlah konsumsi tempe dengan tingkat kepercayaan 99 persen. 
Tabel 3. Hasil analisis regresi linier berganda faktor-faktor yang mempengaruhi jumlah konsumsi tempe

\begin{tabular}{|c|c|c|c|}
\hline Variabel & Koefisien & Sign & VIF \\
\hline Konstanta (C) & $-9,447$ & 0,068 & \\
\hline Harga tahu $\left(\mathrm{X}_{2}\right)$ & 0,413 & 0,290 & 3,218 \\
\hline $\begin{array}{l}\text { Harga ikan asin } \\
\left(\mathrm{X}_{4}\right)\end{array}$ & $-0,308 * * *$ & 0,006 & 1,061 \\
\hline $\begin{array}{l}\text { Harga telur ayam } \\
\left(\mathrm{X}_{5}\right)\end{array}$ & $0,366 * * *$ & 0,009 & 1,185 \\
\hline $\begin{array}{l}\text { Pendapatan } \\
\text { keluarga }\left(\mathrm{X}_{6}\right)\end{array}$ & $0,740 *$ & 0,122 & 3.530 \\
\hline $\begin{array}{l}\text { Jumlah anggota } \\
\text { keluarga }\left(\mathrm{X}_{7}\right)\end{array}$ & $0,588 * *$ & 0,042 & 1,050 \\
\hline F-hitung & 4,401 & 0,002 & \\
\hline R-squared $\left(\mathrm{R}^{2}\right)$ & 0,290 & & \\
\hline Adj R-Squared & 0,224 & & \\
\hline $\begin{array}{r}\text { Keterangan: } \\
* * * \mathrm{~T} \\
* * \mathrm{~T} \\
* \mathrm{~T}\end{array}$ & $\begin{array}{l}\text { signifikasi sebesa } \\
\text { ignifikasi sebesar } \\
\text { ignifikasi sebesar }\end{array}$ & & \\
\hline
\end{tabular}

Secara matematis bentuk model fungsi faktorfaktor yang mempengaruhi jumlah konsumsi tempe adalah

$$
\begin{aligned}
\ln Y= & 0,001+0,413 \ln \mathrm{X}_{2}-0,308 \ln \mathrm{X}_{8}+ \\
& 0,366 \ln \mathrm{X}_{5}+0,704 \ln \mathrm{X}_{6}+0,588 \ln \mathrm{X}_{7}
\end{aligned}
$$

Harga ikan asin merupakan salah satu variabel yang berpengaruh nyata terhadap jumlah konsumsi tempe dengan koefisien -0,308. Artinya, setiap terjadi kenaikan harga ikan asin sebesar 100 persen, maka jumlah konsumsi tempe menurun sebesar 30,80 persen $(0,39 \mathrm{~kg})$. Nilai koefisien antara variabel harga ikan asin dengan jumlah konsumsi tempe bernilai negatif. Berdasarkan teori elastisitas silang, dapat diketahui bahwa antara tempe dan ikan asin merupakan barang komplementer (saling melengkapi). Artinya rumah tangga mengonsumsi tempe dan ikan asin secara bersamaan.

Harga telur ayam merupakan salah satu variabel yang berpengaruh nyata terhadap jumlah konsumsi tempe dengan tingkat koefisien sebesar 0,366. Artinya setiap kenaikan harga telur ayam sebesar 100 persen, maka jumlah konsumsi tempe akan meningkat sebesar 36,60 persen $(0,47 \mathrm{~kg})$. Nilai koefisien antara harga telur ayam dengan jumlah konsumsi tempe bernilai positif. Berdasarkan teori elastisitas silang, dapat diketahui bahwa tempe dengan telur ayam bersifat saling substitusi. Saat harga telur ayam naik, rumah tangga memilih memperbanyak konsumsi tempe untuk memenuhi kebutuhan proteinnya.

Pendapatan keluarga merupakan salah satu faktor yang berpengaruh nyata terhadap jumlah konsumsi tempe dengan koefisien regresi sebesar 0,740. Artinya setiap terjadi kenaikan pendapatan sebesar 100 persen, maka jumlah konsumsi tempe akan meningkat sebesar 74 persen $(0,95 \mathrm{~kg})$. Hal tersebut sesuai dengan teori Lipsey dkk (1995) yang menyatakan bahwa semakin tinggi pendapatan seseorang, maka daya beli terhadap barang tersebut akan meningkan dan sebaliknya. Penelitian ini sejalan dengan penelitian Hanafi, Daris, dan Rochaeni (2014) yaitu variabel pendapatan merupakan faktor yang mempengaruhi permintaan tempe di Kelurahan Jurangmangu Timur, Pondok Aren, Tangerang Selatan dengan tingkat kepercayaan 90 persen.

Jumlah anggota keluarga merupakan salah satu faktor yang berpengaruh nyata terhadap jumlah konsumsi tempe dengan tingkat kepercayaan 90 persen dan koefisien regresi sebesar 0,558. Artinya setiap terjadi kenaikan jumlah anggota keluarga sebesar 100 persen, maka jumlah konsumsi tempe akan meningkat sebesar 58,80 persen $(0,76 \mathrm{~kg})$. Semakin banyak anggota keluarga maka rumah tangga jumlah tempe yang dikonsumsi lebih banyak. Penelitian ini sejalan dengan penelitian tentang produk olahan kedelai lainnya oleh Ariesman, Prasmatiwi dan Indriani (2015) yaitu jumlah anggota keluarga berpengaruh nyata positif terhadap permintaan kecap manis di Bandar Lampung.

\section{KESIMPULAN}

Berdasarkan hasil penelitian dapat disimpulkan bahwa rata-rata jumlah konsumsi tahu keluarga prasejahtera adalah sebesar 2.017,50 gram/minggu atau 288,21 gram/hari, sedangkan untuk tempe sebesar 1.296,50 gram/minggu atau 185,21 gram/hari. Frekuensi konsumsi tahu dan tempe oleh keluarga prasejahtera sangat sering. Tujuan konsumsi tahu dan tempe adalah memenuhi kesukaan dan kebiasaan dengan cara digoreng dan ditumis. Keluarga prasejahtera memperoleh tahu dan tempe dengan cara membeli sendiri. Faktorfaktor yang mempengaruhi jumlah konsumsi tahu adalah harga tahu, harga telur ayam dan jumlah anggota keluarga, sedangkan faktor-faktor yang mempengaruhi jumlah konsumsi tempe adalah harga ikan asin,harga telur ayam, pendapatan keluarga dan jumlah anggota keluarga.

\section{DAFTAR PUSTAKA}

Apriani R, Yuliana, dan Kasmita. 2012. Pola konsumsi ikan pada anak balita di Nagari Taruang-Taruang Kecamatan Rao Kabupaten 
Pasaman. E-Journal Home Economic and Tourism, 1 (1) : 1-15. http://ejournal.unp.ac. id/indexphp/jhet/article/view/518. [14 Oktober 2017].

Ariesman LS, Prasmatiwi FE, dan Indriani Y. 2015. Permintaan dan kepuasan konsumen rumah tangga dalam mengonsumsi kecap di Bandar Lampung. JIIA, 3 (2) : 211-218. http://jurnal.fp.unila.ac.id/index.php/JIA/articl e/view/1041/946. [30 November 2016].

Beritagar.id. 2017. Survei : Jatim Paling Doyan Tahu dan Tempe. https://beritagar.id/artikel/ infografik/survei-jatim-paling-doyan-tahu-dan -tempe. [12 September 2018].

BKP [Badan Ketahanan Pangan]. 2015. Statistik Ketahanan Pangan Indonesia 2014. http:// bkp.pertanian.go.id/berita-341-statistik-ketaha nan-pangan-tahun-2014.html. [20 November 2016].

BPS [Badan Pusat Statistik] Pusat. 2017. Ringkasan Eksekutif Pengeluaran dan Konsumsi Penduduk Indonesia Tahun 2017. https://www.bps.go.id/publication/2017/12/28 /36de91a6f2342f85354ccba5/ringkasanekseku tifpengeluarandankonsumsipendudukindonesi amaret2017.html. [1 Maret 2018].

BPS [Badan Pusat Statistik] Provinsi Lampung. 2016. Pola Konsumsi Penduduk Provinsi Lampung Tahun 2016. https://lampung.bps. go.id/publication/2017/04/13/75e26b75f0e0de f47cb5b534/polakonsumsipendudukprovinsila mpung2016.html. [5 November 2016].

BPS [Badan Pusat Statistik] Kota Bandar Lampung. 2015. Kota Bandar Lampung dalam Angka Tahun 2014. https://bandar lampungkota.bps.go.id/publication/2015/01/0 2/af414fed869e67eba8cc345d/kota-bandar-la mpung-dalam-angka-2014.html. [23 Maret 2017].
Dinas Koperasi dan UMKM. 2016 . Daftar UMK Pengrajin Tempe Tahu di Kota Bandar Lampung. Bandar Lampung.

Departemen Kesehatan. 2015. Daftar Komposisi Bahan Makanan. Bharatara Karya Aksara. Jakarta.

Hanafi FI, Daris E, dan Rochaeni S. 2014. Analisis faktor-faktor yang mempengaruhi permintaan tempe di Kelurahan Jurangmangu Timur, Pondok Aren, Tangerang Selatan. Jurnal Agribisnis, 8 (1) : 45-58. http:// journal.uinjkt.ac.id/index.php/agribusiness/arti cle/view/5128. [14 Oktober 2017].

Indriani Y. 2014. Gizi dan Pangan (Buku Ajar). Universitas Lampung. Bandar Lampung.

Jayati LD, Madanijah S, dan Khomsan A. 2014. Pola konsumsi pangan, kebiasaan makan dan densitas gizi pada masyarakat Kaepuhan Ciptagelar Jawa Barat. Jurnal Penelitian Gizi dan Makanan.Vol 34, No 1 2014. http:// ejournal.litbang.depkes.go.id/index.php/pgm/a rticle/view/4006. [15 Oktober 2017].

Lipsey, Richard G, Courant PN, Purvis DD, dan Steiner PO. 1995. Pengantar Mikroekonomi, Edisi Kesepuluh Jilid satu. Binarupa Aksara. Jakarta.

Parulian J, Lestari DAH, dan Adawiyah R. 2014. Pola konsumsi daging sapi oleh rumah tangga di Bandar Lampung. JIIA, 2 (4) : 364-371. http://jurnal.fp.unila.ac.id/index.php/JIA/articl e/view/991/896. [29 November 2016].

Sugiarto, Siagian D, Sunaryanto LT, dan Oetomo DS. 2003. Teknik Sampling. Gramedia. Jakarta.

Suhardjo. 1986. Pangan, Gizi, dan Pertanian. Universitas Indonesia. Jakarta. 1989. Berbagai Cara Pendidikan Gizi. PT. Bumi Aksara. Jakarta.

Sukirno S. 2003. Pengantar Teori Ekonomi Mikro. PT Salemba Empat. Jakarta. 